\title{
Pengaruh Jenis Nasi Terhadap Nilai Gizi dan Mutu Kimiawi Nasi Dalam Kemasan Selama Penyimpanan Sebagai Alternatif Pangan Darurat
}

\author{
Giyatmi $^{1)}$, Desy Dwi Anggraini ${ }^{2)}$ \\ 1)Jurusan Teknologi Pangan, Universitas Sahid Jakarta
}

\begin{abstract}
Indonesia is often hit by natural disasters that affect to impaired access and damage to infrastructure so that people evacuate emergencies. Discontinuation of victims' access to facilities and infrastructure resulting condition does not allow for disaster victims get adequate food. Network outages to the disaster site is also one thing that adds to the difficulties of food distribution to the victims. The aim of this research was to determine the effect of storage packaged rice on the nutritional value and chemical parameter (water activity and $\mathrm{pH}$ value). The various rice are Nasi Uduk, Nasi Ulam, and Nasi Kuning were packaged in aluminium foil material and sterilized at $121^{\circ} \mathrm{C}$ for 45 minutes. Products were observed at 0, 2, 4, 6 and 8 week. This research was using Randomized Block Design with three treatments and five groups. There was the effect of various rice on chemical parameter ( $\mathrm{pH}$ value) of packaged rice during storage, but various rice did not affect water activity of packaged rice during storage. All various rice meets IOM standard as emergency food which fulfill energy needs. Its total energy contribution was almost $500 \mathrm{kcal}$ and it is recommended to consume this product at least 3-4 times per a day to fulfill the daily energy requirement.
\end{abstract}

Keywords : Rice, emerging food, packaging, Nasi Uduk, Nasi Ulam, Nasi Kuning

\begin{abstract}
ABSTRAK. Indonesia sering kali dilanda bencana alam yang mengakibatkan terputusnya akses dan rusaknya infrastruktur sehingga masyarakat mengungsi keadaan darurat. Terputusnya akses korban terhadap sarana dan prasarana mengakibatkan kondisi tidak memungkinkan bagi para korban bencana mendapatkan pangan yang layak. Terputusnya jaringan ke lokasi bencana juga menjadi salah satu hal yang menambah kesulitan distribusi pangan terhadap korban bencana. Tujuan dari penelitian ini adalah untuk mengetahui pengaruh penyimpanan nasi kemasan terhadap nilai gizi dan parameter kimia (aktivitas air dan nilai pH). Nasi Uduk, Nasi Ulam, dan Nasi Kuning dikemas dalam bahan aluminium foil dan disterilkan pada $121^{\circ} \mathrm{C}$ selama 45 menit. Produk yang diamati pada 0, 2, 4, 6 dan 8 minggu. Penelitian ini menggunakan Rancangan Acak Kelompok dengan tiga perlakuan dan lima kelompok. Terdapat pengaruh jenis nasi terhadap $\mathrm{pH}$ nasi kemasan selama penyimpanan, namun tidak berpengaruh terhadap aktivitas air selama penyimpanan. Semua berbagai jasi memenuhi standar IOM sebagai makanan darurat yang memenuhi kebutuhan energi. Kontribusi energi total hampir $500 \mathrm{kkal}$ dan dianjurkan untuk mengkonsumsi produk ini setidaknya 3-4 kali per hari untuk memenuhi kebutuhan energi harian.
\end{abstract}

Kata Kunci : pangan darurat, pengemasan, Nasi Uduk, Nasi Ulam, Nasi Kuning 


\section{PENDAHULUAN}

Indonesia sering kali dilanda bencana alam yang mengakibatkan terputusnya akses dan rusaknya infrastruktur sehingga masyarakat mengungsi keadaan darurat. Berdasarkan data dari Badan Nasional Penanggulangan Bencana (BNPB) (2015) menyebutkan bahwa jumlah kejadian bencana di Indonesia dari tahun 2013 sampai 2015 adalah sebanyak 5060 kejadian. Terputusnya akses korban terhadap sarana dan prasarana mengakibatkan kondisi tidak memungkinkan bagi para korban bencana mendapatkan pangan yang layak. Terputusnya jaringan ke lokasi bencana juga menjadi salah satu hal yang menambah kesulitan distribusi pangan terhadap korban bencana.

Salah satu upaya dalam menghadapi kesulitan dalam bencana adalah dengan adanya pangan darurat. Menurut Institue of Medicine (IOM) (2003) pangan darurat merupakan bentuk pangan yang dikonsumsi saat terjadi bencana, seperti kebakaran, banjir, kekeringan, wabah penyakit, maupun bencana akibat kesalahan manusia.

Pemberian pangan darurat bertujuan untuk mencegah timbulnya penyakit bahkan kematian akibat kelaparan di saat bencana. Menurut Zoumas (2002), pangan darurat yang potensial dan praktis untuk dikembangkan adalah makanan dengan nutrisi tinggi yang sesuai dengan asupan harian selama 15 hari terhitung dari mulai terjadi bencana. Adapun kebutuhan energi dalam keadaan darurat adalah sebesar $2100 \mathrm{kkal}$ per hari (IOM, 2002). Pangan darurat yang banyak digunakan saat ini adalah nasi bungkus yang tidak dapat bertahan untuk dikonsumsi lebih lama atau mi instan yang memerlukan proses lebih lanjut. Dalam kondisi pasca bencana sangat sulit mendapatkan air bersih, sumber api dan peralatan untuk memasak. Oleh karena itu diperlukan pangan yang praktis tetapi memiliki sifat pangan yang dapat dikonsumsi sehari - hari.
Sesuai dengan budaya dan kebiasaan orang Indonesia yang selalu mengkonsumsi nasi untuk pemenuhan kebutuhan dan mengenyangkan, masih terdapat stigma "belum kenyang kalau belum makan nasi" menandakan betapa masyarakat Indonesia memiliki budaya makan nasi yang kuat (Haryadi, 2006). Terdapat banyak olahan nasi yang cukup dikenal di masyarakat Indonesia, seperti nasi uduk, nasi ulam dan nasi kuning. Jenis - jenis nasi ini memiliki cita rasa yang lebih gurih dari nasi putih biasa karena menggunakan bumbu - bumbu pada saat proses pengolahannya. Oleh karena itu dilakukan penelitian mengenai pangan berbasis nasi dalam kemasan alumunium foil. Kemasan aluminium foil merupakan kemasan yang mudah didapatkan, lebih ringan dan lebih ekonomis dibandingkan kaleng.

Masalah penelitian dibatasi pada jenis nasi selama penyimpanan. Secara keseluruhan dibuat tiga jenis produk nasi dalam kemasan dari nasi uduk, nasi kuning dan nasi ulam. Lama penyimpanan sebagai berikut, pada minggu ke-0, 2, 4, 6 dan 8. Mutu produk ditentukan dengan menggunakan parameter uji kimia. Uji kimia yang dilakukan adalah pengukuran aktivitas air dan nilai $\mathrm{pH}$. Pengujian terhadap parameter penunjang juga dilakukan dari produk nasi dalam kemasan. Parameter yang dipilih adalah parameter kimia dengan uji proksimat (kadar air, kadar abu, lemak, protein, dan karbohidrat), pengujian ini dilakukan pada saat awal penyimpan minggu ke-0 dan dilakukan pengujian kembali setelah produk terindikasi mengalami kerusakan.

\section{METODE PENELITIAN}

\section{Alat dan Bahan}

Alat yang adalah neraca analitik, spatula, piala gelas, pengaduk kaca, stopwatch, hot plate, pisau, talenan, baskom, panci, dan heat sealer. Alat- alat yang digunakan dalam analisis laboratorium terdiri dari alat autoclave dan bunsen. Bahan yang 
digunakan dalam pembuatan nasi dalam kemasan adalah beras, santaim, kunyit, minyak, bawang putih, daun salam, sereh, jeruk nipis, daging, bawang merah, bawang putih, cabai, ikan teri, kacang tanah, garam dan gula.

\section{Proses Pembuatan}

Nasi dalam kemasan yang baik akan membentuk tekstur nasi yang sesuai (tidak terlalu keras maupun lunak). Oleh karena itu perlu dilakukan pengolahan nasi untuk mendapat tekstur seperti yang diharapkan. Tahapan pembuatan nasi dpaat dilihat sebelumnya pada Gambar 1. Pengolahan dimulai dengan menimbang bahan baku sesuai takaran formulasi yang telah dihitung. Kemudian dilakukan pencucian dengan air bersih untuk beras dan bahan bahan lainnya. Air dan bahan - bahan selain beras dimasak terlebih dahulu hingga mendidih. Setelah mendidih beras yang sudah dicuci dimasukkan ke dalamnya untuk menjadi nasi aron dengan menggunakan api kecil yang tidak terlalu panas. Api yang terlalu panas dapat menyebabkan penyerapan air pada beras tidak merata dan akibatnya dapat terbentuk kerak gosong yang dapat merusak cita rasa produk. Kemudian nasi aron tersebut dikukus hingga menjadi nasi matang.

Selama proses pemasakan tersebut, terjadi pengembangan granula pati. Adanya kandungan makromolekul selain pati, seperti lemak atau protein juga dapat memengaruhi proses pengembangan granula. Menurut Rooney dan Lucas (2001), lemak akan berinteraksi dengan granula pati dan mencegah terjadinya hidrasi sehingga menurunkan viskositas pati. Komponen makromolekul lain juga dapat menahan atau menghalangi pengembangan granula yang akhirnya berpengaruh terhadap pembentukan tekstur nasi. Oleh karena itu, penambahan minyak (sumber lemak) pada pemasakan nasi ulam dilakukan setelah pengaronan selesai agar lemak tidak menggangu proses gelatinisasi beras.
Pemasakan lauk sebagai bahan penunjang yaitu lauk sambal teri kacang dan daging dendeng. Proses pemasakan sambal teri dilakukan dengan menimbang bahan - bahannya kemudian dilakukan penggorengan kacang tanah hingga matang. Selain itu pemasakan bumbu bumbu seperti cabai, bawang putih, garam, gula dan ikan teri ditumis dengan minyak hingga matang. Kemudian dimatikan kompor. Setelah itu dimasukkan kacang yang telah digoreng ke dalamnya hingga merata.

Selain Sambal teri kacang, digunakan juga lauk daging dendeng sebagai bahan penunjang lainnya. Daging dicuci terlebih dahulu kemudian dimasak menggunakan bumbu - bumbu seperti gula, garam, jahe, lengkuas, bawang merah dan bawang putih serta air. Pemasakan ini dilakukan hingga air menjadi habis terserap oleh daging. Kemudian setelah itu dilakukan pemotongan menjadi bagian - bagian tipis daging. Daging - daging tipis tersebut kemudian digoreng hingga matang.

Setelah proses pemasakan dilakukan proses pengemasan nasi ke dalam wadah aluminium foil dan lauk dikemas dalam kemasan kantong aluminium. Pengemasan nasi dan lauk dilakukan dengan kemasan berbeda dikarenakan akan nasi tidak mudah menjadi basi dikarenakan tercampur dengan lauk. Nasi yang telah dikemas dalam wadah alumunium dan lauk dalam kantong alumunium ini kemudian dikemas lagi ke dalam kantong alumunium. Tahapan selanjutnya adalah sterilisasi nasi dalam kemasan dengan menggunakan autoclave dengan suhu $121^{\circ} \mathrm{C}$ dan tekanan $1 \mathrm{~atm}$ selama 45 menit.

Sterilisasi ini merupakan proses pemanasan sampai mencapai suhu diatas titik didih untuk mematikan semua mikroorganisme beserta spora sporanya. Pada umumnya diperlukan pemanasan selama 15 menit pada suhu $121^{\circ} \mathrm{C}$ atau ekivalennya. Mengingat bahwa perambatan panas melalu bahan kemasan makanan seperti kaleng, gelas dan bahan pangan memakan waktu dalam 
prakteknya pemanasan dilakukan dalam autoklaf akan memakan waktu lebih lama dari 15 menit, pada nasi dalam kemasan ini menggunakan waktu 45 menit untuk proses sterilisasi (Effendi, 2009).

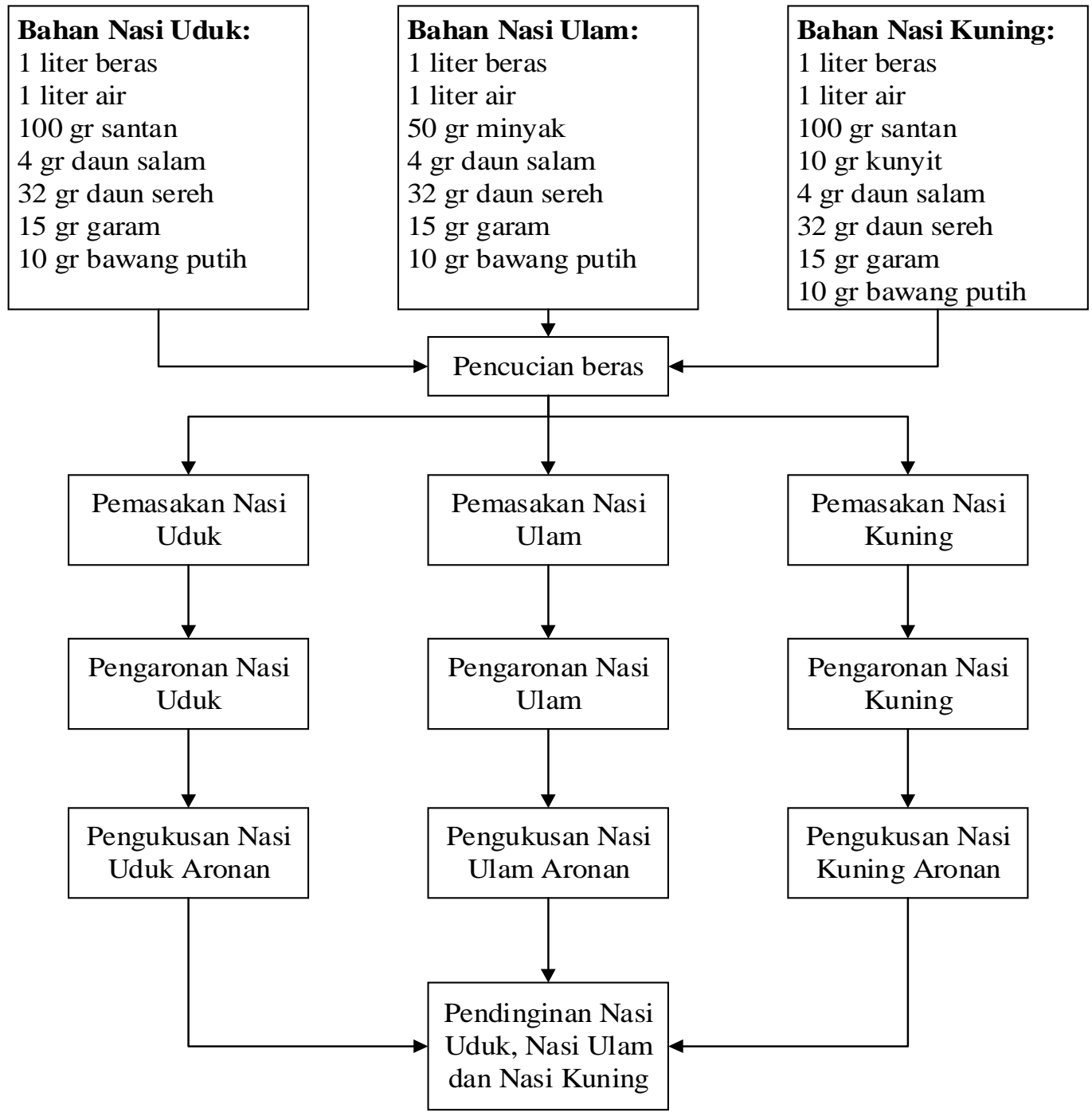

Gambar 2. Tahapan pembuatan nasi uduk, nasi ulam dan nasi kuning
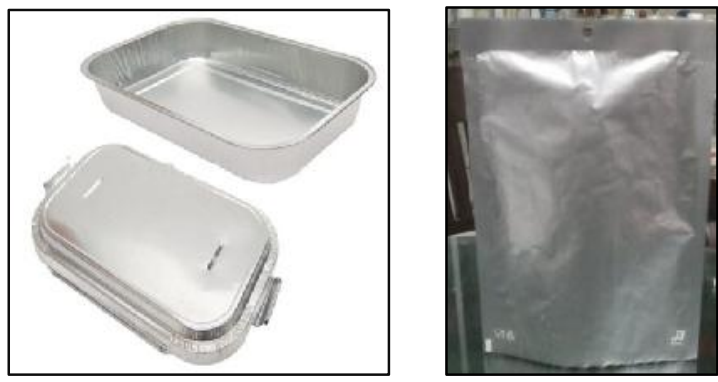

Gambar 1. Wadah dan kantong aluminium 


\section{Teknik Pengumpulan Data}

Data yang dikumpulkan adalah data utama yang meliputi $\mathrm{pH}, \mathrm{Aw}$, Data penunjang berupa mutu kimia berupa kadar air, kadar abu, kadar karbohidrat, kadar lemak dan kadar protein. Penyimpanan dilakukan pada suhu ruang yaitu sekitar $30^{\circ} \mathrm{C}$ selama $0-8$ minggu.

Aktivitas air dari sampel diukur dengan menggunakan $a_{w}$ meter yang telah dikalibrasi dengan garam $\mathrm{NaCl}$ dengan nilai kelembabannya $(\mathrm{RH})$ adalah $75 \%$. Nilai $\mathrm{pH}$ diukur dengan $\mathrm{pH}$-meter yang telah dikalibrasi dengan Larutan buffer $\mathrm{pH}$ 7 dan $\mathrm{pH}$ 4. Analisis proksimat dilakukan untuk mengukur Kadar Air (AOAC, 2005); Kadar Abu (AOAC, 2005); Kadar Protein (AOAC, 2005); Kadar Lemak (AOAC, 2005); dan Kadar Karbohidrat (by difference).

\section{Teknik Analisis Data}

Data hasil penelitian dianalisis secara deskriptif dan inferensial. Analisis data secara deskriptif dilakukan untuk mengetahui kecenderungan pengaruh faktor penelitian terhadap mutu nasi dalam kemasan dengan jenis nasi dan lama penyimpanan berbeda. Pengolahan data dalam bentuk nilai rata-rata disajikan dalam bentuk diagram.

Analisis data secara inferensial dilakukan untuk menguji hipotesis penelitian. Teknik analisis yang digunakan adalah metode analisis varian (ANAVA) dengan 3 taraf perlakuan yaitu jenis nasi dan 5 blok kelompok yaitu lama penyimpanan. Pengolahan data dilakukan menggunakan perangkat lunak Statistical Package for
Social Science (SPSS). ANAVA digunakan untuk melihat pengaruh dari setiap faktor penelitian bila ada pengaruh dilakukan uji lanjut DMRT (Duncan Multiple Range Test). Uji DMRT dilakukan untuk melihat taraf utama yang menghasilkan perbedaan mutu.

\section{HASIL DAN PEMBAHASAN}

\section{Formulasi Nasi Dalam Kemasan}

Tahap formulasi bertujuan untuk merancang produk nasi dalam kemasan yang sesuai dengan persyaratan yang telah ditetapkan oleh Institute of Medicine (2002), yaitu produk harus memiliki sebaran kontribusi energi dari makromolekul kabohidrat sebesar 40$50 \%$, protein $10-15 \%$ dan lemak $35-45 \%$. Target formulasi produk adalah nilai kalori yang cukup yaitu 500 - $700 \mathrm{kkal} /$ hari untuk memenuhi kecukupan $2100 \mathrm{kkal} / \mathrm{hari}$, dengan asumsi setiap orang akan mengonsumsi produk sebanyak tiga kali dalam sehari. Dalam hal ini, kontribusi zat gizi mikro dan mineral tidak wajib diperhitungkan karena komponen mikro tidak menyumbang secara signifikan terhadap kalori produk (Muchtadi, 2002).

Bahan baku yang digunakan sebagai bahan utama adalah beras sebagai sumber karbohidrat serta lauk penunjang yaitu daging dendeng dan sambal teri kacang sebagai sumber protein dan lemak. Tahap formulasi diawali dengan mengetahui komposisi gizi bahan baku yang digunakan untuk dapat menghitung komposisi gizi dan kontribusi kalori seimbang dari masing - masing formulasi secara teoritis (Tabel 1).

Tabel 1. Komposisi bahan baku

\begin{tabular}{|c|c|c|c|c|c|}
\hline \multirow{2}{*}{ Bahan Baku } & \multicolumn{4}{|c|}{ Komposisi (gram) } & \multirow{2}{*}{$\begin{array}{l}\text { Kalori } \\
\text { (Kkal) }\end{array}$} \\
\hline & Berat & $\mathbf{K H}$ & Protein & Lemak & \\
\hline Beras & 50 & 40 & 3.75 & - & 175 \\
\hline Daging Sapi & 50 & - & 10 & 6 & 95 \\
\hline Ikan Teri & 25 & - & 10 & 6 & 95 \\
\hline Kacang Tanah & 20 & 8 & 6 & 3 & 80 \\
\hline
\end{tabular}




\section{Kupas}

\begin{tabular}{lccccc} 
Minyak Goreng & 5 & - & - & 5 & 45 \\
Santan & 50 & - & - & 5 & 45 \\
Kunyit & 100 & 14 & 13 & 58 & 325 \\
Gula & 8 & - & 7.5 & - & 30 \\
\hline \multicolumn{7}{c}{ Sumber : Almatsier (2010) }
\end{tabular}

Komponen karbohidrat diharapkan menjadi komponen utama pada pangan darurat, karena energi dari karbohidrat bersifat siap pakai dan cepat diurai oleh metabolisme tubuh (Muchtadi, 2002). Hal ini penting bagi masyarakat yang berada pada kondisi darurat yang asupan energi cepat sangat dibutuhkan. Selain karbohidrat, produk pangan darurat juga membutuhkan kandungan lemak yang cukup. Hal ini disebabkan oleh lemak yang memiliki kontribusi sangat besar terhadap pemenuhan energi. Kontribusi 1 gram lemak setara dengan 9.2-9.3 kkal atau 2 kali lipat lebih besar daripada karbohidrat (Astawan 2004).
Data komposisi bahan baku ini penting untuk melakukan perhitungan komposisi bahan baku agar dapat memenuhi persyaratan IOM. Tahapan perhitungan komposisi bahan baku dilakukan menggunakan prinsip kesetimbangan massa (mass balance), yaitu setiap material yang masuk (input) harus memiliki jumlah yang sama dengan akumulasi yang terjadi selama proses dan hasil luaran (output) yang dihasilkan (Hariyadi 2006). Adapun komposisi bahan penyusun nasi dalam kemasan dapat dilihat pada Tabel 2.

Tabel 1. Komposisi (gram) bahan penyusun nasi dalam kemasan

\begin{tabular}{lccc}
\hline \multicolumn{1}{c}{ Bahan } & Nasi Uduk & Nasi Ulam & Nasi Kuning \\
\hline a) Nasi & & & \\
Beras & 100 & 100 & 100 \\
Santan & 12.5 & 0 & 12.5 \\
Minyak & 0 & 6.25 & 0 \\
Kunyit & 0 & 0 & 1.25 \\
Sereh & 4 & 4 & 4 \\
Salam & 0.5 & 0.5 & 0.5 \\
Garam & 2 & 2 & 2 \\
Bawang Putih & 1.25 & 1.25 & 1.25 \\
Jeruk nipis & 1 & 1 & 1 \\
Air & 125 & 125 & 125 \\
& & & \\
b) Lauk Sambal Teri Kacang & & & \\
Ikan Teri & 2.5 & 2 & 2.5 \\
Kacang Tanah & 10 & 8 & 10 \\
Minyak & 4.5 & 3.6 & 4.5 \\
Gula & 0.25 & 0.2 & 0.25 \\
Bawang merah & 0.8 & 0.64 & 0.8 \\
Bawang putih & 0.8 & 0.64 & 0.8
\end{tabular}




\begin{tabular}{lccc}
\hline \multicolumn{1}{c}{ Bahan } & Nasi Uduk & Nasi Ulam & Nasi Kuning \\
\hline $\begin{array}{l}\text { c) Lauk Daging Dendeng } \\
\text { Daging sapi }\end{array}$ & & & \\
Gula & 40.5 & 30.4 & 40.5 \\
Minyak & 1.2 & 0.9 & 1.2 \\
Jahe & 9.5 & 7.2 & 9.5 \\
Lengkuas & 1.9 & 1.4 & 1.9 \\
Bawang merah & 2.4 & 1.8 & 2.4 \\
Bawang putih & 3.8 & 2.9 & 3.8 \\
Garam & 3.8 & 2.9 & 3.8 \\
Total Kalori (kkal) & 0.6 & 0.45 & 0.6 \\
\hline
\end{tabular}

Keterangan : Perhitungan bahan baku diakukan dalam satuan gram

Hasil perhitungan secara teori menunjukkan bahwa sebaran energi pada produk sudah memenuhi kriteria menurut Institue of Medecine. Nilai kalori adalah berkisar 600 kkal untuk setiap produk dengan takaran saji 235 gram untuk nasi uduk dan nasi kuning. Takaran saji untuk nasi ulam adalah 227 gram. Porsi takaran untuk setiap kemasan dapat dilihat pada Tabel 3.

Tabel 2. Porsi nasi dalam kemasan

\begin{tabular}{cccc}
\hline \multirow{2}{*}{ Jenis Nasi } & \multicolumn{3}{c}{ Takaran Tiap Kemasan (gr) } \\
\cline { 2 - 4 } & Nasi & Sambal Teri Kacang & Daging Dendeng \\
\hline Nasi Uduk & 200 & 15 & 20 \\
Nasi Kuning & 200 & 15 & 20 \\
Nasi Ulam & 200 & 12 & 15 \\
\hline
\end{tabular}

Ditinjau dari segi gizi dan kontribusi energi, ketiga formula yang disusun sudah memenuhi kriteria IOM (2002) berdasarkan kontribusi energi makro yang sudah dihitung dengan persentase sebaran energi pada Tabel 4.

Tabel 4. Perhitungan sebaran energi secara teoritis

\begin{tabular}{ccccc}
$\begin{array}{c}\text { Sebaran Energi } \\
\text { dari }\end{array}$ & Nasi Uduk & Nasi Ulam & Nasi Kuning & Standar IOM \\
\hline Karbohidrat & 49.72 & 49.35 & 49.52 & $40-50$ \\
Protein & 13.02 & 13.46 & 13.04 & $10-15$ \\
Lemak & 37.37 & 37.31 & 38.12 & $35-45$ \\
\hline
\end{tabular}

\section{Aktivitas air}

Aktivitas air adalah air bebas yang terkandung dalam bahan yang dapat digunakan oleh mikroba untuk pertumbuhannya. Aktivitas air sangat menentukan pertumbuhan berbagai mikroorganisme yang terdapat pada bahan pangan (Estiasih, 2009). Pengukuran aktivitas air dilakukan dengan menggunakan $a_{w}$ meter. Hasil pengukuran aktivitas air nasi dalam kemasan dapat dilihat pada Gambar 3. 


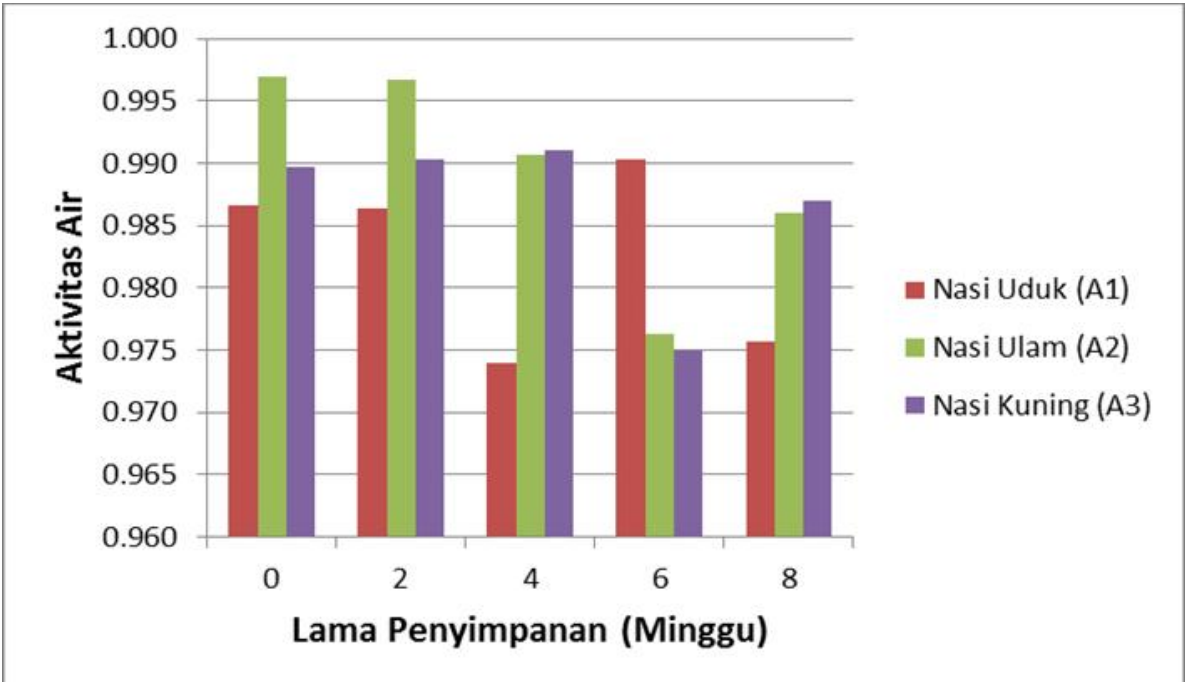

Gambar 3. Grafik aktivitas air nasi dalam kemasan

Diketahui bahwa aktivitas air nasi dalam kemasan yang dihasilkan berkisar pada 0.970-0.997. Aktivitas air pada nasi dalam kemasan cenderung menurun dengan semakin lamanya waktu penyimpanan. Gambar 3 menujukkan bahwa pada 0 minggu sampai 4 minggu aktivitas air tertinggi adalah nasi ulam dan yang terendah adalah nasi uduk. Pada 6 minggu aktivitas air tertinggi adalah nasi uduk dan terendah adalah nasi kuning. Pada 8 minggu aktivitas tertinggi adalah nasi kuning dan terendah adalah nasi uduk. Aktivitas nasi uduk untuk setiap lama penyimpanan selalu berbeda - beda. Aktivitas nasi ulam untuk setiap lama penyimpanan selalu menurun dari 0 minggu sampai 6 minggu dan naik kembali pada 8 minggu. Aktivitas air nasi kuning pada 0 minggu sampai 4 minggu relatif stabil, kemudian menurun pada 6 minggu dan naik kembali pada 8 minggu.

Berdasarkan hasil analisis sidik ragam (ANAVA) pengukuran aktivitas air nasi dalam kemasan menunjukkan bahwa tingkat signifikasi jenis nasi sebesar 0.36. Nilai signifikasi tersebut lebih besar $(>)$ 0.05 yang berarti $\mathrm{HO}$ diterima. Hal ini berarti bahwa ada tidak pengaruh atau perbedaan yang nyata dari jenis nasi terhadap aktivitas air nasi dalam kemasan selama penyimpanan.

\section{Nilai pH}

Salah satu faktor pada pangan yang mempengaruhi pertumbuhan mikroba adalah nilai $\mathrm{pH}$, yaitu suatu nilai yang menunjukkan keasaman atau kebasaan. Dengan menggunakan $\mathrm{pH}$-meter, nilai $\mathrm{pH}$ suatu bahan dapat diukur, umumnya berkisar antara 0 sampai 14 . Nilai $\mathrm{pH} 7$ menunjukkan bahan yang netral, nilai $\mathrm{pH}$ kurang dari 7 menunjukkan bahan bersifat lebih asam, sedangkan nilai $\mathrm{pH}$ lebih dari 7 menunjukkan bahan lebih bersifat basa. Kebanyakan mikroba tumbuh baik pada $\mathrm{pH}$ sekitar netral, dan $\mathrm{pH} 4,6-7,0$ merupakan kondisi optimum untuk pertumbuhan bakteri, sedangkan kapang dan kamir dapat tumbuh pada $\mathrm{pH}$ yang lebih rendah. Pengelompokan pangan berdasarkan nilai $\mathrm{pH}$-nya adalah pangan berasam rendah yang memiliki nilai $\mathrm{pH} 4.6$ atau lebih dan pangan asam yang memiliki pH 3.7 - 4 (Kusnandar, 2010). Nasi dalam kemasan ini termasuk dalam kategori pangan berasam rendah. Pengukuran $\mathrm{pH}$ untuk setiap waktu penyimpanan nasi dapat dilihat pada Gambar 4. 


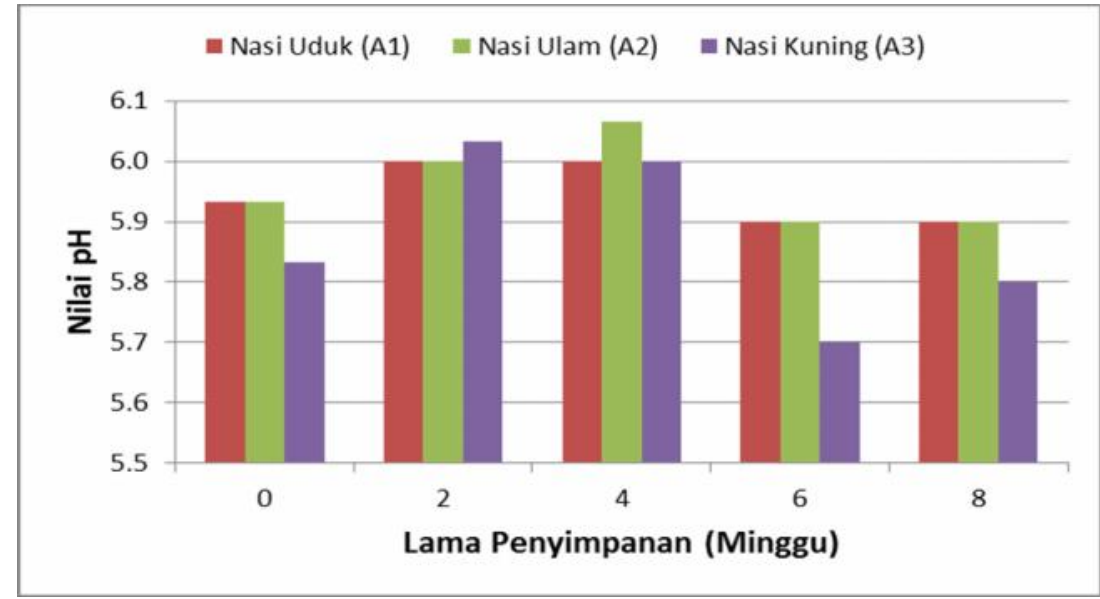

Gambar 4. Pengukuran nilai pH nasi dalam kemasan

Diketahui bahwa pH dalam kemasan yang dihasilkan berkisar pada 5.5-6.5. Hal ini berarti nasi dalam kemasan termsauk golongan pangan berasam sedang (mendekati netral). Gambar 4 menunjukkan nilai $\mathrm{pH}$ pada 0 minggu cenderung meningkat untuk semua jenis nasi sampai 4 minggu, selanjutnya menurun dari 6 minggu sampai 8 minggu.

Hasil analisis sidik ragam (ANAVA) pengukuran nilai $\mathrm{pH}$ nasi dalam kemasan menunjukkan bahwa tingkat signifikasi jenis nasi sebesar 0.03 lebih kecil $(<) 0.05$ yang berarti $\mathrm{H} 0$ ditolak dan $\mathrm{H} 1$ diterima. Hal ini berarti bahwa ada pengaruh atau perbedaan yang nyata dari jenis nasi terhadap nilai $\mathrm{pH}$ nasi dalam kemasan selama penyimpanan. Hasil uji beda rata rata Duncan (DMRT) menunjukkan bahwa nasi kuning berbeda nyata dari jenis nasi lainnya, sedangkan nasi uduk tidak berbeda nyata dengan nasi ulam.

\section{Analisis Proksimat Produk}

Analisis proksimat terhadap produk dilakukan untuk memastikan hasil perhitungan sebaran gizi yang telah dilakukan sebelumnya (secara teoritis) dengan sebaran gizi aktual yang terdapat pada produk. Analisis proksimat dilakukan terhadap parameter kandungan karbohidrat, lemak, protein, abu dan air. Hasil analisis proksimat produk dalam kemasan dapat dilihat pada Tabel 5.

Tabel 5. Hasil analisis proksimat

\begin{tabular}{lcccc}
\hline \multicolumn{2}{c}{ Analisis Proksimat (\%) } & Nasi Uduk & Nasi Ulam & Nasi Kuning \\
\hline \multirow{2}{*}{ Kadar Karbohidrat } & Awal & 29.32 & 27.22 & 26.78 \\
\multirow{2}{*}{ Kadar Protein } & Akhir & 32.13 & 30.71 & 28.87 \\
\multirow{2}{*}{ Kadar Lemak } & Awal & 8.59 & 8.51 & 7.80 \\
& Akhir & 7.26 & 6.09 & 6.60 \\
Kadar Abu & Awal & 9.37 & 9.39 & 8.60 \\
& Akhir & 7.61 & 7.73 & 7.31 \\
& Awal & 1.35 & 1.10 & 1.32 \\
& Akhir & 1.38 & 1.24 & 1.51
\end{tabular}




\begin{tabular}{lllll} 
Kadar Air & Awal & 51.37 & 53.78 & 55.50 \\
& Akhir & 51.63 & 54.22 & 55.71 \\
\hline
\end{tabular}

Keterangan: Kadar analisis awal dilakukan pada 0 minggu dan kadar analisis akhir dilakukan pada 8 minggu

Berdasarkan hasil analisis proksimat dapat dilakukan perhitungan persentase sebaran nasi dalam kemasan adalah dengan cara sebagai berikut dan hasil perhitungan energi pada Tabel 6 .

$$
\begin{aligned}
& \text { \% Sebaran KH }=\frac{\text { Kadar karbohidrat } x \text { bobot per porsi } x 4}{\text { total energi }} \times 100 \% \quad \ldots 1 \\
& \% \text { Sebaran Protein }=\frac{\text { Kadar protein } x \text { bobot per porsi } x 4}{\text { total energi }} \times 100 \% \quad \ldots 2 \\
& \text { \% Sebaran Lemak }=\frac{\text { Kadar lemak } x \text { bobot per porsi } x 9}{\text { total energi }} \times 100 \% \quad \ldots 3
\end{aligned}
$$

Tabel 3. Hasil perhitungan jumlah energi setiap porsi nasi dalam kemasan

\begin{tabular}{llccccccc}
\hline \multirow{2}{*}{ Energi dari } & \multicolumn{2}{c}{ Nasi Uduk } & \multicolumn{2}{c}{ Nasi Ulam } & \multicolumn{2}{c}{ Nasi Kuning } & \multirow{2}{*}{ IOM } \\
\cline { 3 - 8 } & & kkal & $\%$ & Kkal & $\%$ & kkal & $\%$ & (\%) \\
\hline KH & Hitung & 331.81 & 49.72 & 316.41 & 49.35 & 332.48 & 49.52 & $40-50$ \\
& Awal & 277.91 & 50.84 & 247.15 & 50.00 & 251.75 & 50.80 & \\
\multirow{4}{*}{ Protein } & Akhir & 300.78 & 56.86 & 277.53 & 56.02 & 270.17 & 55.61 & \\
& Hitung & 86.89 & 13.02 & 86.30 & 13.46 & 87.55 & 13.04 & $10-15$ \\
& Awal & 69.47 & 12.59 & 56.64 & 11.20 & 63.27 & 12.51 & \\
& Akhir & 69.47 & 12.84 & 56.64 & 11.12 & 63.27 & 12.70 & \\
Temak & Hitung & 249.39 & 37.37 & 239.22 & 37.31 & 255.94 & 38.12 & $35-45$ \\
& Awal & 198.23 & 36.57 & 191.81 & 38.80 & 181.83 & 36.69 & \\
& Akhir & 160.91 & 30.30 & 163.56 & 32.86 & 154.65 & 31.69 & \\
& Hitung & 667.35 & 100.00 & 641.16 & 100.00 & 671.41 & 100.00 & 2,100 \\
& Awal & 545.62 & 100.00 & 495.60 & 100.00 & 496.85 & 100.00 & per hari \\
& Akhir & 531.16 & 100.00 & 497.73 & 100.00 & 488.08 & 100.00 & \\
\hline
\end{tabular}

Keterangan: Teori adalah perhitungan secara manual berdasarkan referensi, kadar analisis awal dilakukan pada 0 minggu dan kadar analisis akhir dilakukan pada 8 minggu

Pada Tabel 6 menunjukkan bahwa hasil sebaran energi menunjukkan bahwa terdapat perbedaan antara hasil perhitungan teoritis dengan hasil analisis awal dan juga akhir, Perbedaan hasil teori dengan analisis proksimat awal relatif tidak besar (perbedaan kurang dari $5 \%$ ). Hal ini diduga karena perhitungan teoritis tidak memperhitungkan kemurnian aktual dari bahan baku. Hasil analisis proksimat awal berbeda dengan hasil akhir. Hasil proksimat kadar karbohidrat meningkat sedangkan kadar lemak menurun. Kadar lemak menurun karena terjadi keluarnya minyak dari lauk nasi dalam kemasan sehingga menempel pada kemasan dan berkurang dari lauk. Sedangkan kadar karbohidrat menurun akibat kurangnya kadar lemak pada nasi dalam kemasan.

\section{KESIMPULAN DAN SARAN}

\section{Kesimpulan}

1. Terdapat pengaruh nyata jenis nasi terhadap mutu kimia (nilai $\mathrm{pH}$ ) nasi dalam kemasan selama penyimpanan, sedangkan jenis nasi tidak mempengaruhi secara nyata terhadap aktivitas air dalam kemasan selama penyimpanan.

2. Semua jenis nasi memenuhi standar IOM yaitu pangan darurat yang dapat memenuhi kebutuhan kalori. 


\section{Saran}

Perlu dilakukan pengujian mutu mikrobiologi dan organoleptik untuk melihat tingkat kerusakan mikrobiologis dan penerimaan konsumen selama penyimpanan.

\section{DAFTAR PUSTAKA}

AOAC, 2005. Official Methods of Analysis. Washington D.C. The Association of Official Agricultural Chemists.

Badan Nasional Penanggulangan Bencana. 2015. Statistik Kejadian Bencana di Indonesia. Jakarta. BNPB.

Effendi, H. M. S. 2009. Teknologi Pengolahan dan Pengawetan Pangan. Alfabeta. Bandung.

Estiasih, T. dan Ahmadi, K. 2009. Teknologi Pengolahan Pangan. Jakarta. PT. Bumi Aksara.

Haryadi. 2006. Teknologi Pengolahan Beras. Yogyakarta. Gadjah Mada University Press

Institute of Medicine. 2003. High-Energy, Nutrients-Dense Emergency Relief Food Product. Washington D.C. National Academy Press.

Zoumas BL dan Amstrong LE. 2002, High Energy, Nutrient, Dense Emergency Relief Product. National Press Academy. Washington. 
